\title{
Fostering Awareness and Acceptance of Disability in Mexican Mothers of Autistic Children
}

\author{
Alfa Celene Rea Amaya1, Guadalupe Acle Tomasini2 \\ ${ }^{1}$ Facultad de Psicología, Universidad Nacional Autónoma de México, Mexico City, México \\ ${ }^{2}$ Facultad de Estudios Superiores Zaragoza, Universidad Nacional Autónoma de México, Mexico City, México \\ Email: celenere1982@hotmail.com,gaglet@unam.mx
}

Received 1 June 2014; revised 25 June 2014; accepted 15 July 2014

Copyright (C) 2014 by authors and Scientific Research Publishing Inc. This work is licensed under the Creative Commons Attribution International License (CC BY). http://creativecommons.org/licenses/by/4.0/

(c) (i) Open Access

\section{Abstract}

The arrival of a disabled child is overwhelming to any family; it is often a shocking event that impacts the life cycle of the family. Several studies highlight the support that must be provided to parents of children with disabilities. In Mexico, this support is not often promoted in a successfully way neither in official nor private institutions. The purpose of this study was to assess the effect of a special assistance program carried out with five autistic children' mothers, aged between 28 and 43 years $\left(M_{\text {age }}=35.4\right)$. Attention was focused on: family functioning, knowledge and acceptance of disability. We used a mixed design with a concurrent triangulation; the study was non-experimental, ex post facto, descriptive, and cross-cutting. The main findings show that this program had a positive effect on mothers and several changes regarding the studied variables were observed. It was important to highlight that there was one unexpected result: the personal and group empowerment that enabled the participants, on the one hand, to acknowledge themselves as women in a couple relationship and not only as mothers of their disabled child, and, on the other hand, to form a network of mothers who can look for legal and administrative protection for their autistic children.

\section{Keywords}

Mothers of Children with Disabilities, Autism, Knowledge of Disabilities, Acceptance of Disability, Family Functioning

\section{Introduction}

When families are expecting a child, expectations grow up around them. In all likelihood, the child's health and 
the possibility that they might be born with a disability will play into the hopes and fears of parents at some point, only to be downplayed and cast aside because of the fear itself (Kezban et al., 2013; Núñez, 2008; Ortega, Salguero, \& Garrido, 2007). Of course, no parent hopes for their children to be disabled, and the arrival of a child who does not match expectations, and who will require greater efforts in terms of care and education, is an issue that can often destabilize the family unit (Doron \& Sharabany, 2013; Gargiulo, 2012; Machin, Purón, \& Castillo, 2009; Núñez, 2008; Rosman, 1991; Soulé, 2009). Frequently, such a situation can be overwhelming and will affect the family throughout its lifetime (Rosman, 1991; Sarto, 2001; Viloria \& Guinea, 2012).

Mexican families of children with disabilities have certain needs related to the disability that are not adequately met, and support is therefore required to allow them access to health, rehabilitation and education services. This lack of care can stem from several factors, including service shortages, parents not having sufficient information and knowledge, and failure to join a suitable care network. After all, difficulties are encountered on a daily basis when it comes to accessing the services that these families require, causing even everyday activities to become burdensome (Gobierno del Distrito Federal, DIF-DF, UNICEF, 2006; Vargas et al., 2012). The number of families in Mexico which have at least one member with disabilities is not known (Programa Nacional para el Desarrollo de las Personas con Discapacidad 2009-2012, 2009). Indeed, it would be extremely advantageous to identify Mexican families that do have a disabled child so that they can be given the support necessary.

We have seen from clinical experience that, for assistance provided to parents to be appropriate and to improve the functioning of families of children with disabilities, our objective must be to make the adaptation period for coming to terms with the circumstances as short as possible. The process for accepting disability will vary depending on the nature of the disability in question (Sarto, 2001). Therefore, we need to work with the parents of children with disabilities at the same time as we work with the children themselves.

Gómez (2008) writes that it is vital to work with the families of these children in order to gain a better understanding of the problems they face and to help them find solutions that will enable them to perform their role successfully. The attitudes of parents of children with disabilities shape the strength and stability of family and social relationships in harmony. It has been proved that, if parents are given proper coaching and guidance, they can positively influence most areas of their child's development (Jiménez, Lugo, \& Morales, 1999). Heward (2007) argues that active family participation is of vital importance in continuous educational planning, and further predicts that helping and coaching families will become key objectives in working with children with disabilities.

Most research focuses on the mothers of children with disabilities, since it is they who have the most contact with the child and become their primary caregivers, due to the gender roles that are learned in our society (Caples \& Sweeney, 2010; Espina \& Ortego, 2003; Núñez, 2008). Rowbotham, Carroll, \& Cuskelly (2011) state that mothers provide $40 \%$ more care for children than fathers do. Providing assistance to mothers of children with disabilities plays an essential role in the comprehensive care that they require, since this can improve family wellbeing and support resources, and can be of use in their children's education, can improve the quality of life of both the child and the family, and can prove excellent in regulating family functioning.

Furthermore, it is important to work with mothers of children with disabilities to promote greater understanding, acceptance and handling of disabilities, as well as healthy family functioning. This can be achieved through assistance programs aimed at solving the issues that these mothers have to deal with. It is important that these are assessed before planning, that there is an attempt at outreach towards and understanding of mothers, and that there is a raising of awareness prior to the assistance program (Doron \& Sharabany, 2013; Jiménez, Lugo, \& Morales, 1999). Vélez (2001) explains that parent-targeted programs are a resource that must provide support for parents to develop skills that benefit their child with disabilities. Espina \& Ortego (2003) indicate that all assistance programs must be preceded and led by an assessment, then evaluated following their implementation to find out how effective they have been.

When it comes to designing parent-targeted assistance programs, it is important to create an environment that encourages meaningful learning, to assess the needs of the participants, to observe the family characteristics such as lifestyle, socio-economic and cultural factors, to share experiences, and to develop skills for putting everything learnt into practice (Doron \& Sharabany, 2013; Vélez, 2001), thus enabling a greater understanding and acceptance of the disability concerned and a better functioning within families of children with disabilities. Literature in the subject indicates that the starting point for planning these services must be to look at the overall needs of the children and their families within their own particular environment (Carlson, Armitstead, Rodger, \& Liddle, 2010). It is therefore important to implement assistance programs in Mexico that promote family in- 
volvement, since the better prepared they are, the more progress they will make in the process of accepting and handling disability, with this support allowing the family respite and the enjoyment of other aspects of their lives (Espina \& Ortego, 2003; Steel, Poppe, Vandevelde, Van Hove, \& Claes, 2011).

Parent-targeted assistance programs have been an effective resource in supporting child development. However, scant theoretical and practical research has been carried out in Mexico which would contribute to optimizing their efficiency (Acle-Tomasini, 2013; Sánchez, 2006; Sánchez, Acle, de Agüero, Jacobo, \& Rivera, 2003; Vélez, 2001). These programs have centered on holding workshops to promote power and authority among fathers and/or mothers of children with mental handicaps (Saad, 2000); talks aiming to encourage positive changes in parents' attitudes towards their children with Down's Syndrome, and to solve issues caused by these children at home (Blas, 2005); workshop-courses for parents of children with emotional and behavioral disturbances, providing parents with strategies that let them develop skills that benefit their child's socio-affective development (Arias \& Tello, 2006); promoting parental support to help those with special educational needs to integrate into the social and school environment (López, 2007); workshops that inform and counsel parents on their child's disability through development and learning support strategies, helping them to identify stages of grief (Delgadillo, 2007); workshops for parents of children with mental handicaps to raise awareness, provide information and guide families on aspects of behavior, norms, values and personal attitudes, to promote advocacy and self-advocacy (Beltrán \& Pacheco, 2007); workshops for mothers of children with special educational needs, which facilitate the self-discovery process by way of identifying their emotions and how these affect their bodies (Ávila, 2008); and workshops aimed at furthering parents' understanding of family and its structural components, so that they can amend the structures and organizations that hinder its development (Mateos, 2010).

These kinds of proposals and studies of Mexican parents of children with disabilities are simply not enough, since each one only sets out to monitor one of the variables under study within the target population. This has led us to design an assistance program in which other variables are also taken into account; a program targeted at mothers of children with disabilities, as we aim to assess the effects of its implementation in three areas: family functioning, understanding, and acceptance of disability.

\section{Method}

\subsection{Type of Study}

This is a descriptive, non-experimental and cross-cutting study. It uses a concurrent triangulation design, collecting and analyzing quantitative and qualitative data at the same time as the assistance program for parents of children with disabilities is being implemented (Creswell, 2003; Hernández, Fernández, \& Baptista, 2010).

\subsection{Participants}

Five mothers of children with permanent disabilities, who have requested external medical and psychological care for their child, and who are attending the Child Rehabilitation Center (C.R.I. in Spanish) in Mexico City. They have agreed to participate voluntarily in this assistance program.

In the ethical interests of this study, Table 1 shows the details of each participant alongside the nickname used and chosen by each mother during an introductory activity carried out during the program's first session.

Table 1. Details of assistance program participants.

\begin{tabular}{cccccc}
\hline Name & Age & Level of Education & Occupation & Diagnosis of the Child \\
Giraffe & 28 & Psychology Undergraduate (Unfinished) & Housewife & Autism \\
Table & 33 & Secondary School & Manicurist & Pervasive Development Disorder \\
Doll & 43 & Degree in Hospitality and Cuisine & Housewife & Atypical Autism \\
Duck & 37 & Bachelor Degree in Law & Housewife & Autism \\
EB & 36 & Degree in Textiles & Tailor's Assistant & Cerebral Palsy \\
\hline
\end{tabular}




\subsection{Instruments}

1) Questionnaire on understanding of disability (Rea \& Acle, 2011). This was prepared following a thematic exploration into the understanding of disability as discussed in international literature, whereby different topics were analyzed such as definitions of disability, classifications and types of disability, and characteristics of congenital disability, as well as international rights and Mexican legislation on the rights of people with disabilities. It comprises 10 open-ended questions. The questionnaire can be answered individually or in groups.

2) Family Functioning Scale (García, Rivera, Reyes-Lagunes, \& Díaz-Loving, 2007). This is a summative composite instrument (like Lickert) made up of 45 items presented in the form of illustrations-22 positive and 23 negative-which are in turn grouped into 4 sections (Family environment, Hostility/conflict avoidance, Control/problems expressing feelings and Cohesion/rules). The instrument contains five response intervals, numbered from one to five: $1=$ never, $2=$ hardly ever, $3=$ sometimes, $4=$ frequently and $5=$ always. The total Cronbach's Alpha score was .8533.

3) Semantic Differential for parents of children with disabilities. (Rea, Ampudia, \& Acle, 2010). This assessment consists of 25 pairs of opposite adjectives in relation to disability, which can be used to describe the child, whereby the mother is asked to place her child in one category for each pair, leading off from the question: "What feelings does a child with disabilities evoke in me?" It is composed of a list of adjectives that the mothers must associate with the item proposed, using adjectives that are bipolar and encompass both extremes. The differential presents four response categories: completely, fairly, slightly and normal. This is a pen and paper exercise that is carried out individually or in groups. It has been verified by experts in educational psychology, with $95 \%$ agreement.

4) Assistance program for mothers of children with disabilities. Its implementation brought together elements encompassing group, family and games therapy. The assessment criteria used both quantitative and qualitative procedures. The program comprised 15 sessions of approximately 4 hours each, split into three units which addressed the topics of: I. Understanding disability (4 sessions); II. Accepting disability (5 sessions); and III. Family functioning (6 sessions), in which different techniques were used for each topic.

\subsection{Procedure}

The necessary procedures for attending the Children's Rehabilitation Center (C.R.I.) in Mexico City were followed and completed in order to implement the assistance program. Upon instrument authorization, the participants attended one day a week for approximately 4 hours, over a 4 month period, for a total of approximately 68 hours. We selected mothers who were attending psychological consultations with their children at the C.R.I., who satisfied the selection criteria and agreed to participate voluntarily in the study. As such, they signed an informed consent form and the confidentiality of all information provided by them was guaranteed. Although five mothers participated at the start of the program, one had to leave the program in the fourth session because her disabled daughter was due to undergo a tendon operation. As such, the sample comprised four participants from the second unit onwards.

Unit I was assessed at the beginning and at the end with a questionnaire. For units II and III, the mothers answered the following question in writing at the end of each session: What have I, as the mother of a child with disabilities, learnt from this session? The activities carried out during the sessions of units II and III were analyzed and inserted in the "my child's scrapbook", which the mothers kept at the end of the program. Throughout the program, a research logbook was kept to back up the assistance program analysis.

During the first session, a quantitative assessment was carried out in groups, using the Family Functioning Scale, the Semantic Differential and the questionnaire on understanding disability, the post-test of which was conducted at the end of unit I. Two weeks after the final week of the assistance program, post-tests were carried out for the other instruments. For the qualitative assessments of units II and III (10 sessions), the following data collection strategies were employed: a) Session logbook; b) Participant assessment of each session, and; c) Participant assessment of the course.

\subsection{Data Analysis}

The non-parametric Wilcoxon signed-rank test was used to analyze the quantitative results for the three variables. The results of this test were used to measure the effect size (Oblitas, 2008; Ozer, 2007; Shaughnessy, Zechmeister, \& Zechmeister, 2007). To analyze the qualitative results, data collection strategies were employed, 
including a session development logbook, participant assessment of each session, and participant assessment of the course. The following categories of analysis were established using the information obtained during the assistance program:

- Understanding disability: How mothers get information about, explain and experience their child's disability.

- Accepting disability: The state of mind in which targeted efforts are made to recognize, understand and resolve the problems (Gargiulo, 2012) encountered by mothers of children with disabilities in order to accept them.

- Family Functioning: The set of relationship patterns in place between family members throughout its life cycle, which are enacted in view of the established roles and influence of the social environments where they interact. Assessed in terms of family environment, hostility/conflict avoidance, control/problems expressing feelings, and cohesion/rules (García, 2007).

\section{Results}

\subsection{Understanding Disability}

The results demonstrate that mothers had a poor understanding of their child's disability, scoring between 2 and 5 points out of 10 from all items. After the assistance program, we noticed statistically significant differences in the Wilcoxon test results $(p=0.042)$, which suggests that they gained a better understanding of their child's disability. There was a proven impact in terms of the effect size, bearing in mind that the sample size was small (5 mothers), since the effect size was large $(r=0.5, d=0.8)$ in accordance with Oblitas (2008), Ozer (2007), Shaughnessy et al. (2007).

Mothers began to ask questions about the differences between disabilities. During this unit of the program, they realized that although their children sometimes shared diagnoses and behavior, every child had specific characteristics, as illustrated below.

"Our children have the same diagnosis, but they're not the same. Each has his own characteristics" (EB).

Another objective was for mothers to learn about the law-enshrined Mexican and international rights of people with disabilities, in order to raise awareness of their entitlements and legal protection status. The mothers voiced some concerns over these issues. They had never given much thought to legal considerations before the program, and they now began to do so. This is illustrated in the following statements:

“Will my son lose his medical entitlements when he’s 25?” (Doll).

"How can I protect my son by leaving him my inheritance? I fear that I'll leave him unprotected when I die" (Giraffe).

"Could I have a copy of the articles of the convention so that I can pass them to the kindergarten teacher and the parents of the other kids in the group, so that they know my son's rights?” (Duck).

At the start of the assistance program, it was clear that the mothers had little information, whereas at the end of the first unit, they were able to identify, learn and recognize information that related to their children's disability, which would help them to understand their capabilities and limitations. They also applied the rights of their children, as individuals with disabilities, in their everyday lives. Once they were aware of these rights, they raised questions about their children's medical care, and the best way to make sure that they were legally protected should they or their husbands pass away. Throughout the program, the mothers researched, looked into and cast aside their concerns over this issue.

We were constantly aware throughout this unit that mothers required a greater understanding and further knowledge about their child's diagnosis. They began by searching online, but could not find reliable information, and their concerns remained, or became even more confused. This is consistent with the findings of Keenan, Dillenburger, Doherty, Byme, \& Gallagher (2010), who say that parents experience high levels of stress when trying to access and find out information relevant to their child's condition. In the same vein, Cabezas \& Fonseca (2007), Viloria \& Guinea (2012) indicate that the parents of children with disabilities hold a number of misconceptions over the characteristics of the disability, and they go on to highlight the importance of getting as early a diagnosis as possible in order for support and education to be provided that will help reduce levels of stress, rejection, denial, feelings of ambivalence, pessimism, distress, and anxiety, all of which hinder the child's comprehensive development. Wakimizu, Fujioka, \& Yoneyama (2010), on the other hand, argue that, as well as 
information on the actual diagnosis, mothers require information on how to bring up a child with disabilities. Whereas, Kezban et al. (2013), Marcheti, Noda, \& Ferreira (2007), Martínez \& Bilbao (2008), Masood, Turner, \& Baxter (2007), Pérez \& Lorenzo (2007), Torres \& Maia (2009) agree that mothers must receive comprehensive information on their child's disability in order for the family to benefit in terms of how the child is treated and related with. By receiving information about the disability and about treatment options for their child, mothers' concerns or anxieties are eased considerably and they can adopt a more positive attitude towards the disability.

We noticed at the beginning of the program that the mothers had a poor understanding of disability, but as the first unit went on, they became more informed. This is consistent with the observations made by the authors cited above, and of Huang, Tsai, \& Kellett (2011), who argue that clear information can empower families, which can use the knowledge and abilities thus obtained to make better decisions, to plan for medical care, and to benefit from coping better, an increased sense of autonomy, and a reduced sense of impotence, fear, anxiety, uncertainty, and stress.

\subsection{Accepting Disability}

In the Semantic Differential pre-test, we noticed that the emotions triggered by having a child with disabilities were largely negative, and the Wilcoxon test that was employed following the assistance program $(p=0.068)$ did not show any statistically significant differences in this regard. However, by looking at the effect size, we noticed a proven impact, since the effect size is moderate $(r=0.3, d=0.5)$ in accordance with Oblitas (2008), Ozer (2007), Shaughnessy et al. (2007). This is illustrated in the following statements:

"I can see the importance of remembering all the good things and bad things that have happened to us in our lives, and that we have come this far with such special children that we have; that we can overcome obstacles with the help of others and, more importantly, when we accept that help” (Doll).

"In every goal that I set myself, I'm going to succeed by taking slow, short steps. But I'll succeed. I'm certain my daughter will manage to run, speak, and do everything I’ve dreamt for her...” (Table).

"This session has taught me how we look at and experience the condition of our children, and, in particular, how others view our kids. I saw how we fear that the people around our children see someone different, someone else, who should be discriminated against. But it's the other way around; we realized that they love our children and that they understand their disability and know how they should be treated, and, most of all, that we are not alone. It's a question of ability, not disability” (Duck).

"I'm now well aware that my child is dependent on me to make progress. Even though his dad isn't really engaging with him at the moment, it doesn't matter, because I do it and that is enough. Sometimes the people around me don't understand my son's situation, but I can't change the world" (Giraffe).

The above gives an illustration as to how mothers became more relaxed about their children's disabilities as the unit progressed; and as their acceptance grew, they were able to express the negative emotions that their disability triggered in them. At the beginning, they expressed positive emotions, in a show of social desirability, but after working on these emotions and understanding their disability over the course of the program, they became more aware of their child's condition, which led to the changes mentioned above. They were then able to express the negative emotions that their disability triggered in them. They pinpointed that their main problem as mums was that they overprotected their children, and at the end of the program they recognized the importance of doing this less, as illustrated in the following statements:

"This session taught that, by overprotecting my son, I am only limiting his disability further" (Giraffe).

"What I learned from this session is that we should recognize the emotions that our children trigger in us, that we should learn to recognize what they really need, to help them learn to stand up for themselves and not to overprotect them" (Duck).

"We must stop being overprotective for the good of our children. We must find out and reassert who our children are, and talk about our anecdotes and experiences of them” (Doll).

We discussed with the mothers the different kinds of support their children really need. They realized that they tend to be overprotective of their children as a result of their disability (Figure 1); however, they then identify which activities their children could undertake by themselves, which would allow them to be more inde- 


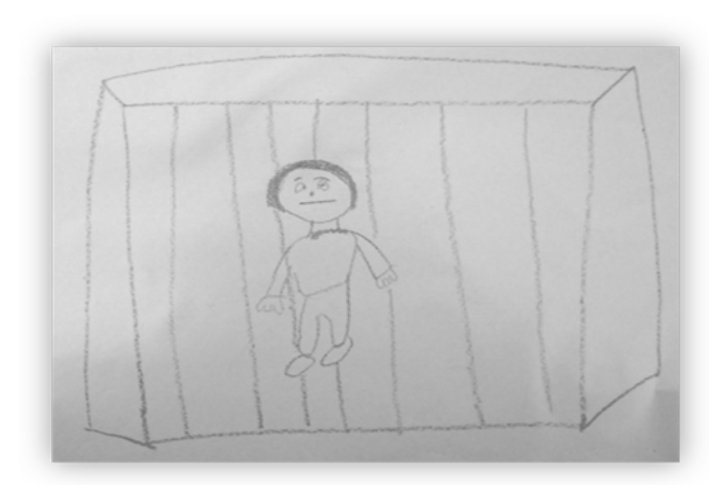

Figure 1. Doll's drawing, illustrating overprotection that she exercises over her son.

pendent. This is illustrated in the following statements:

“...like other mums, I realized that most of us were in agreement about everything we gave up doing when we had children...” (Table).

"My son has very few actual needs. I've been left upset because my son wants to eat alone, and I feel down because he no longer lets me feed him. But at the same time, I'm happy because he's started to gain, or to ask for, independence” (Duck).

The program has helped mothers to identify the behaviors of their children with disabilities and to reflect not only on how they overprotect them, but also on their own dependence on them. In this respect, the findings are consistent with those of Madrigal (2007), who argues that mothers display an emotional interdependence with their children, thinking that they should be with them at all times to prevent them from being exposed to dangers and from being in situations of their own imagination. Similarly, De Lambo, Chung, \& Huang (2011) write that mothers feel stressed due to their child's inability to adapt and adjust to environmental changes. They tend to have difficulties in developing styles of upbringing, and are more overprotective of their disabled child. These circumstances can lead mothers to put their own lives on the backburner, or can lead other family members to do this for them. The natural bond that mothers have with their children means that they keep looking after their disabled child because they think that only they are able to look after them, or that they're obliged to do so (Araya, 2007; Córdoba-Andrade, Gómez-Benito \& Verdugo-Alonso, 2008). It was therefore essential that mothers could witness these situations so that both they and their children could benefit from reduced overprotection, resulting in the child having a certain level of independence and the mother feeling less distressed or guilty about delegating responsibilities to other family members.

\subsection{Family Functioning}

The Family Functioning Scale did not show up any statistically significant differences through the Wilcoxon test $(p=0.273)$. However, by looking at the effect size, we noticed a proven impact, since the effect size is large $(\mathrm{r}=$ $0.5, \mathrm{~d}=0.8$ ) in accordance with Oblitas (2008), Ozer (2007), Shaughnessy et al. (2007). In order to verify this information, we carried out a statistical analysis for each of the four sections that make up the family functioning scale, whereby the Wilcoxon scale did not show up any statistically significant differences, but changes were observed in the effect size. The results are shown in Table 2.

The assistance program highlighted the importance of family communication, and mothers were given various techniques to improve and increase this communication. We also explored how a child's disability diagnosis can affect family members, as illustrated below:

"In this session, I realized that families are deeply affected by the conditions of children with disabilities, but as a mother, you have to face up to such a situation and understand that others don't see this [situation] as we would like them to, which they sometimes end up accepting” (Table).

"My son's disability is hard for me because, at home, my eldest son and my husband don't believe he's autistic. My parents, and my parents in law, say that it's my fault that my son is like he is, because I spoil him” (Doll). 
Table 2. Section results.

\begin{tabular}{cc}
\hline Section & Effect Size \\
\hline Positive family environment & Large $(r=0.5, \mathrm{~d}=0.8)$ \\
Hostility/Conflict avoidance & Small $(\mathrm{r}=0.1, \mathrm{~d}=0.2)$ \\
Control/Problems expressing feelings & Large $(\mathrm{r}=0.5, \mathrm{~d}=0.8)$ \\
Cohesion/Rules & Large $(\mathrm{r}=0.5, \mathrm{~d}=0.8)$ \\
\hline
\end{tabular}

We talked with the group of mothers about the respect and affection that exist in their families and how these can be enhanced. This workshop's success is illustrated in the following statements:

"This session made me realize that our family has grown in love and respect because of my son's disability, particularly in relation to others" (Duck).

"Today I learned about respect: what it is and how affection is expressed inside and outside my family... I loved how family was presented!” (Table).

"It's moving to see how much my daughter is loved by my family (tearful). My daughter is a gift from God" (Table).

Another important issue was the setting of limits and rules within the family. Vargas et al. (2012) describe how parents highlight the need for support in teaching discipline to their disabled child, and Al-Qaisy (2012) writes that providing support to guide mothers in training and caring for children helps reduce emotional and social stress within the family. The following statements illustrate the changes that had taken place in mothers once the sessions that addressed these issues were completed:

"In this session, I realized that I need to set appropriate limits for my son, to be more consistent and to realize that I, too, have rights and obligations" (Giraffe).

"I saw how limits are necessary for family life, and that includes limits appropriate to the needs of the family, and we need to agree and be consistent in that regard" (Duck).

"This session taught me that I need to set limits, even though I find it difficult, but I'll give it a go. It also reminded me of the limits placed on me when I was a child" (Doll).

These findings are consistent with the research of Anderson, Elliott \& Zurynski, 2013; Al-Qaisy, 2012, Islam, Shanaz, \& Farjana, 2013, Kezban et al., 2013, Madrigal, 2007, Núñez, 2008, Olsson \& Hwang, 2008, Pérez \& Lorenzo, 2007, Torres \& Maia, 2009, and other authors, in relation to the impact that the birth of a child with disabilities can have on a family. Over the course of the program, mothers talked about the changes that were occurring in their own families, which were generally positive. This led them to promote enhanced interaction between family members throughout the program in order to create greater unity, to be better positioned when it comes to dealing with crises, to allow family members to talk about their emotions, to encourage individual, personal development in order to achieve increased and improved autonomy, respect, communication, and to set out responsibilities and obligations for each family member. Each of these aspects is consistent with the findings of Pérez \& Lorenzo (2007). Various changes for the better were noted in participants, which will perhaps lead the families of these children to function better and to all members benefitting both individually and as a family.

\section{Discussion}

A child's disability is a trigger for emotional, physical, economic, and social changes within the family. Unfortunately, these changes within are not always positive, since parents have to deal with countless changes, both in a personal capacity and to their families, in their lives. By implementing the assistance program, we were able to observe the lack of information about the disabilities of their children and the shortcomings in emotional and social support provided to them by health institutions. The results obtained through the implementation of this program are consistent with the findings reported by Arias \& Tello (2006), Ávila (2008), Beltrán \& Pacheco (2007), Blas (2005), Delgadillo (2007), López (2007), Mateos (2010), Saad (2000), who noted marked improvements in the mothers who participate in such programs. Although these authors introduce numerous variables in their research, none of them simultaneously covers family functioning, and the understanding and acceptance of disability, which goes to highlight the importance of the study carried out here.

Given that they did not have enough psychosocial support, the impact of disability on mothers who partici- 
pated in the program led to an attitude of resignation, which was consistent with the research carried out by Mora, Córdoba, Bedoya, \& Verdugo (2007). Furthermore, the mothers did not feel sufficiently prepared to educate and address the needs of their disabled child, as we can also see in the study by Marcheti et al. (2008). Pérez \& Lorenzo (2007) highlight the high impact on family functioning and families' quality of life, aspects that are consistent with the responses of the participating mothers.

After the program, there were changes observed in the mothers' relationships with their partners and their families. Such changes can lead to higher levels in terms of the socio-economic functioning of children with disabilities, which is consistent with the studies carried out by Hauser-Cram, Warfield, Shonkoff, \& Krauss (2001), and Mitchell \& Hauser-Cram (2009).

It is worth highlighting that the main goal of this program was to promote changes in family functioning, and understanding and acceptance of disability. However, as well as noticing changes in these three variables, we also observed significant changes in the mothers themselves, as they grew in awareness and the self-determination of their own lives as women in their own right. For example, they realized they had been neglecting their relationships with their partners, their personal care, their social relationships and their careers. Furthermore, since the program was run with a small sample, there was an element of group empowerment which enabled them to forge support networks. By finding that they shared the same hopes and fears for their disabled children, the feelings of loneliness that they had expressed previously changed, although this could be because they will be able to seek better care in the future for their children through the institution. At the beginning, we thought that only having four participants would constitute a limitation for the study, but we recognized as the sessions went on that it was in fact an advantage, since it allowed the mothers more freedom to express their emotions, it encouraged greater trust and group cohesion, and it allowed more time and more individual attention to be spent on the mothers over the course of the sessions.

In conclusion, the design and implementation of the assistance program led to a positive outcome for the mothers, since positive qualitative changes were achieved for all participants, and this would lead us to continue implementing assistance programs of this kind with parents of children with permanent disabilities.

\section{References}

Acle-Tomasini, G. (2013). Investigación en Educación Especial (2002-2011): Logros y Desafíos. In M. De Agüero-Servín (Ed.), Aprendizaje y Desarrollo 2001-2011 (pp. 21-109). Mexico: Consejo Mexicano de Investigación EducativaANUIES.

Al-Qaisy, L. (2012). Mother's Stress in Families of Children with Mental Handicap. Asian Social Science, 8, 80-85. http://dx.doi.org/10.5539/ass.v8n2p80

Araya, S. (2007). De lo Invisible y lo Cotidiano. Familias y Discapacidad. Actualidades Investigativas en Educación, 7, 121.

Arias, A., \& Tello, B. (2006). Curso-Taller para padres: Desarrollo de habilidades socioafectivas en niños con alteraciones en esta área. Mexico: UNAM.

Ávila, A. (2008). Las emociones de las madres de hijos con necesidades educativas especiales: Una propuesta de trabajo desde el enfoque psicosomático y la sensibilización Gestalt. Mexico: UNAM.

Beltrán, L., \& Pacheco, R. (2007). Los padres como promotores de la autodeterminación de sus hijos con discapacidad intelectual. Mexico: UNAM.

Blas, M. (2005). El rechazo de los padres de familia hacia sus hijos con síndrome de down, atendidos en el Centro de Atención Múltiple (C.A.M.) de educación especial de la comunidad de Paracho, Mich., en el año 2002. Mexico: Universidad Don Vasco, Escuela de Trabajo Social.

Cabezas, H., \& Fonseca, G. (2007). Mitos que manejan padres y madres acerca del autismo en Costa Rica. Actualidades Investigativas en Educación, 7, 1-18.

Caples, M., \& Sweeney, J. (2010). Quality of Life: A Survey of Parents of Children/Adults with an Intelectual Disability Who Are Availing of Respite Care. British Journal of Learning Disabilities, 39, 64-72.

Carlson, G., Armitstead, C., Rodger, S., \& Liddle, G. (2010). Parents’ Experiences of the Provision of Community-Based Family Support and Therapy Services Utilizing the Strengths Approach and Natural Learning Environments. Journal of Applied Research in Intellectual Disabilities, 23, 560-572.

Cordoba-Andrade, L., Gómez-Benito, J., \& Verdugo-Alonso, M. (2008). Calidad de vida familiar en personas con discapacidad: Un análisis comparativo. Universitas Psychologica, 7, 369-383.

Creswell, J. (2003). Research Design. Qualitative, Quantitative and Mixed Methods Approaches. Thousand Oaks, CA: Sage. 
De Lambo, D., Chung, W., \& Huang, W. (2011). Stress and Age: A Comparison of Asian American and Non-Asian American Parents of Children with Developmental Disabilities. Journal of Developmental and Physical Disabilities, 23, $129-141$. http://dx.doi.org/10.1007/s10882-010-9211-3

Delgadillo, M. (2007). El trabajo con padres en el centro de atención múltiple No. 30. Bachelor’s Thesis. Mexico City: UNAM, Facultad de Estudios Superiores Iztacala.

Doron, H., \& Sharabany, A. (2013). Marital Patterns among Parents to Autistic Children. Psychology, 4, 445-453. http://dx.doi.org/10.4236/psych.2013.44063

Espina, A., \& Ortego, M. (2003). Discapacidades Físicas y Sensoriales. Aspectos Psicológicos, Familiares y Sociales. Spain: CCS.

García, M. (2007). La infidelidad y su relación con el poder y el funcionamiento familiar: Correlatos y predicciones. Mexico City: UNAM, Facultad de Psicología.

Gargiulo, R. (2012). Special Education in Contemporary Society. An Introduction to Exceptionality. USA: Thomson Learning.

Gobierno del Distrito Federal, DIF-DF, UNICEF (2006). El reto de la inclusión y atención integral de niños, niñas y jóvenes con discapacidad en el Distrito Federal. Mexico.

Gómez, A. (2008). Estrategia educativa para la preparación de la familia del niño y la niña con diagnostico de retraso mental. Cuba: Editorial Universitaria.

Hauser-Cram, P., Warfield, M., Shonkoff, J., \& Krauss, M. (2001). Children with Disabilities: A Longitudinal Study of Child Development and Parent Well-Being. Monographs of the Society for Research in Child Development, 66, 1-131.

Hernández, R., Fernández, C., \& Baptista, P. (2010). Metodología de la investigación. Peru: McGraw-Hill.

Heward, W. (2007). Niños excepcionales. Una introducción a la educación especial. Spain: Prentice Hall.

Huang, Y., Tsai, S., \& Kellett, U. (2011). Fathers of Children with Disabilities: Encounters with Health Professionals in a Chinese Context. Journal of Clinical Nursing, 21, 198-206. http://dx.doi.org/10.1111/j.1365-2702.2011.03826.x

Islam, M. Z., Shanaz, R., \& Farjana, S. (2013). Stress among Parents of Children with Mental Retardation. Bangladesh Journal of Medical Science, 12, 74-80. http://dx.doi.org/10.3329/bjms.v12i1.13354

Jiménez, M., Lugo, G., \& Morales, C. (1999). Perspectivas de los padres sobre los problemas de sus hijos y sobre sus necesidades de asesoría psicológica. In G. Acle-Tomasini (Ed.), Educación Especial: Evaluación, Intervención, Investigación (pp. 491-507). Mexico City: UNAM.

Keenan, M., Dillenburger, K., Doherty, A., Byme, T., \& Gallagher, S. (2010). The Experiences of Parents during Diagnosis and Forward Planning for Children with Autism Spectrum Disorder. Journal of Applied Research in Intellectual Disabilities, 23, 390-397. http://dx.doi.org/10.1111/j.1468-3148.2010.00555.x

Kezban, M., Kaya, E., Incesulu, A., Gulec, G., Cakli, H., Ozudogru, E., \& Colak, E. (2013). Parental Anxiety and Influential Factors in the Family with Hearing Impaired Children: Before and after Cochlear Implantation. The Journal of Applied Research in Intellectual Disabilities, 23, 560-572.

López, N. (2007). La modificación de la estructura y los procesos en la familia de niños con alteraciones de conducta. Mexico City: UNAM, Facultad de Psicología.

Machín, M., Purón, E., \& Castillo, J. (2009). Reflexiones sobre la intervención temprana en niños con síndrome de Down considerando la familia y la comunidad. Revista Habanera de Ciencias Médicas, 8, 1-6.

Madrigal, A. (2007). Familias ante la parálisis cerebral. Intervención Psicosocial, 16, 55-68.

Marcheti, M., Noda, M., \& Ferreira, M. (2008). Experiences of Mothers of Disabled Children: A Phenomenological Study. Acta Paulista de Enfermagem, 21, 46-52. http://dx.doi.org/10.1590/S0103-21002008000100007

Martínez, M., \& Bilbao, M. (2008). Acercamiento a la realidad de las familias de personas con autismo. Intervención Psicosocial, 17, 215-230.

Masood, A., Turner, L., \& Baxter, A. (2007). Causal Attributions and Parental Attitudes toward Children with Disabilities in the United States and Pakistan. Exceptional Children, 73, 475-487. http://dx.doi.org/10.1177/001440290707300405

Mateos, E. (2010). Un miembro con necesidades educativas especiales en la familia: Taller de estructura familiar. Mexico City: UNAM, Facultad de Estudios Superiores Iztacala.

Mitchell, D., \& Hauser-Cram, P. (2009). Early Predictors of Behavior Problems. Two Years after Early Intervention. Journal of Early Intervention, 32, 3-16. http://dx.doi.org/10.1177/1053815109349113

Mora, A., Córdoba, L., Bedoya, A., \& Verdugo, M. (2007). Características de la calidad de vida en familias con un adulto con discapacidad intelectual en la ciudad de Cali, Colombia. Diversitas, 3, 37-54.

Núñez, B. (2008). Familia y discapacidad. De la vida cotidiana a la teoría. Argentina: Lugar Editorial. 
Oblitas, L. (2008). Psicoterapias contemporáneas. Mexico: Cengace Learning.

Olsson, M., \& Hwang, C. (2008). Socioeconomic and Psychological Variables as Risk and Protective Factors for Parental Well-Being in Families of Children with Intellectual Disabilities. Journal of Intellectual Disability Research, 52, 11021113. http://dx.doi.org/10.1111/j.1365-2788.2008.01081.x

Ortega, P., Salguero, A., \& Garrido, A. (2007). Discapacidad: Paternidad y cambios familiares. Avances en Psicología Latinoamericana, 25, 118-125.

Ozer, D. (2007). Evaluating Effect Size in Personality Research. In W. Robins, C. Fraley, \& F. Krueger (Eds.), Handbook of Research Methods in Personality Psychology (pp. 495-501). New York: Guilford.

Pérez, V., \& Lorenzo, Z. (2007). El impacto del déficit mental en el ámbito familiar. Revista Cubana de Medicina General Integral, 23, 1-8.

Programa Nacional para el Desarrollo de las Personas con Discapacidad 2009-2012 (2009). Por un México incluyente: Construyendo alianzas para el ejercicio pleno de los derechos de las personas con discapacidad. Mexico: Secretaria de Salud/Consejo Nacional para las Personas con Discapacidad.

Rosman, B. (1991). El desarrollo familiar y el impacto de la enfermedad crónica de un hijo. In C. Falicov (Ed.), Transiciones de la familia. Continuidad y cambio en el ciclo de vida (pp. 405-428). Argentina: Amorrortu.

Rowbothan, M., Carroll, A., \& Cuskelly, M. (2011). Mothers’ and Fathers’ Roles in Caring for an Adult Child with an Intellectual Disability. International Journal of Disability, Development and Education, 58, 223-240. http://dx.doi.org/10.1080/1034912X.2011.598396

Saad, E. (2000). Programa de facultamiento a padres para promover la autodeterminacion de sus hijos con discapacidad intelectual. Tesis de Maestría no publicada, Mexico City: UNAM, Facultad de Psicología.

Sánchez, P. (2006). Discapacidad, familia y logro escolar. Revista Iberoamericana de Educación, 40, 1-10.

Sánchez, P., Acle, G., De Agüero, M., Jacobo, Z., \& Rivera, A. (2003). Educación especial en México (1990-2001). In Sánchez (Ed.), Aprendizaje y desarrollo, Vol. 4. (pp. 189-375). Mexico: Consejo Mexicano de Investigación Educativa.

Sarto, M. (2001). Familia y Discapacidad. III Congreso "La atención a la diversidad en el sistema educativo". Salamanca: Instituto Universitario de Integración en la Comunidad (INICO).

Shaughnessy, J., Zechmeister, E., \& Zechmeister, J. (2007). Métodos de investigación en psicología. Mexico: McGraw-Hill.

Soulé, G. (2009). Papás especiales para niños especiales. Mexico: Diana.

Steel, R., Poppe, L., Vandevelde, S., Van Hove, G., \& Claes, C. (2011). Family Quality of Life in 25 Belgian Families: Quantitative and Qualitative Exploration of Social and Professional Support Domains. Journal of Intellectual Disability Research, 55, 1123-1135. http://dx.doi.org/10.1111/j.1365-2788.2011.01433.x

Torres, L., \& Maia, E. (2009). Percepción de las madres acerca del contenido de la información del diagnóstico de Síndrome de Down. Revista Chilena de Pediatría, 89, 39-47.

Vargas, C., Arauza, C., Folsom, K., Luna, M., Gutierrez, L., Ohliger, P., Shelton, K., Foreman, C., Waffle, D., Reynolds, R., \& Cooper, P. (2012). A Community Engagement Process for Families with Children with Disabilities: Lessons in Leadership and Policy. Maternal and Child Health Journal, 16, 21-30. http://dx.doi.org/10.1007/s10995-010-0666-8

Vélez, M. (2001). Programa de involucramiento familiar en el aprendizaje y desarrollo del niño del primer ciclo. Unpublished Master's Thesis on Special Education, Tlaxcala: Universidad Autónoma de Tlaxcala.

Viloria, C., \& Guinea, C. (2012). La atención a la familia en atención temprana: Retos actuales. Psicología Educativa, 18, 123-133. http://dx.doi.org/10.5093/ed2012a13

Wakimizu, R., Fujioka, H., \& Yoneyama, A. (2010). Empowerment Process for Families Rearing Children with Developmental Disorders in Japan. Nursing and Health Sciences, 12, 322-328.

http://dx.doi.org/10.1111/j.1442-2018.2010.00533.x 
Scientific Research Publishing (SCIRP) is one of the largest Open Access journal publishers. It is currently publishing more than 200 open access, online, peer-reviewed journals covering a wide range of academic disciplines. SCIRP serves the worldwide academic communities and contributes to the progress and application of science with its publication.

Other selected journals from SCIRP are listed as below. Submit your manuscript to us via either submit@scirp.org or Online Submission Portal.
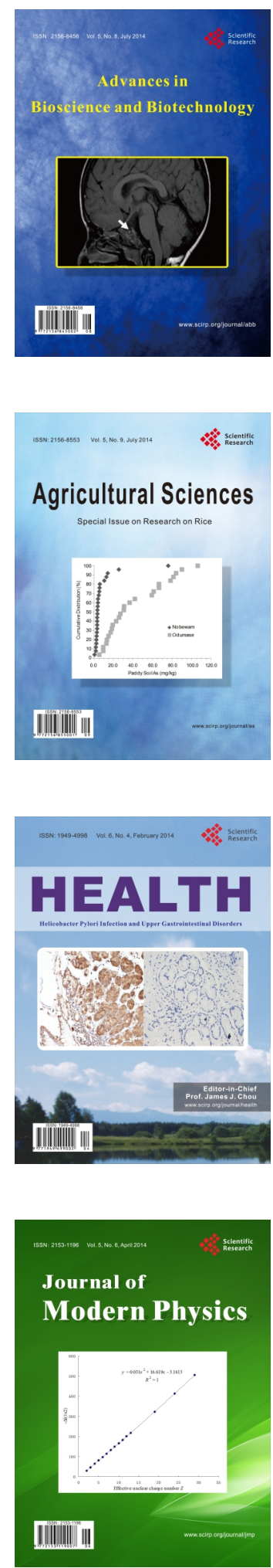
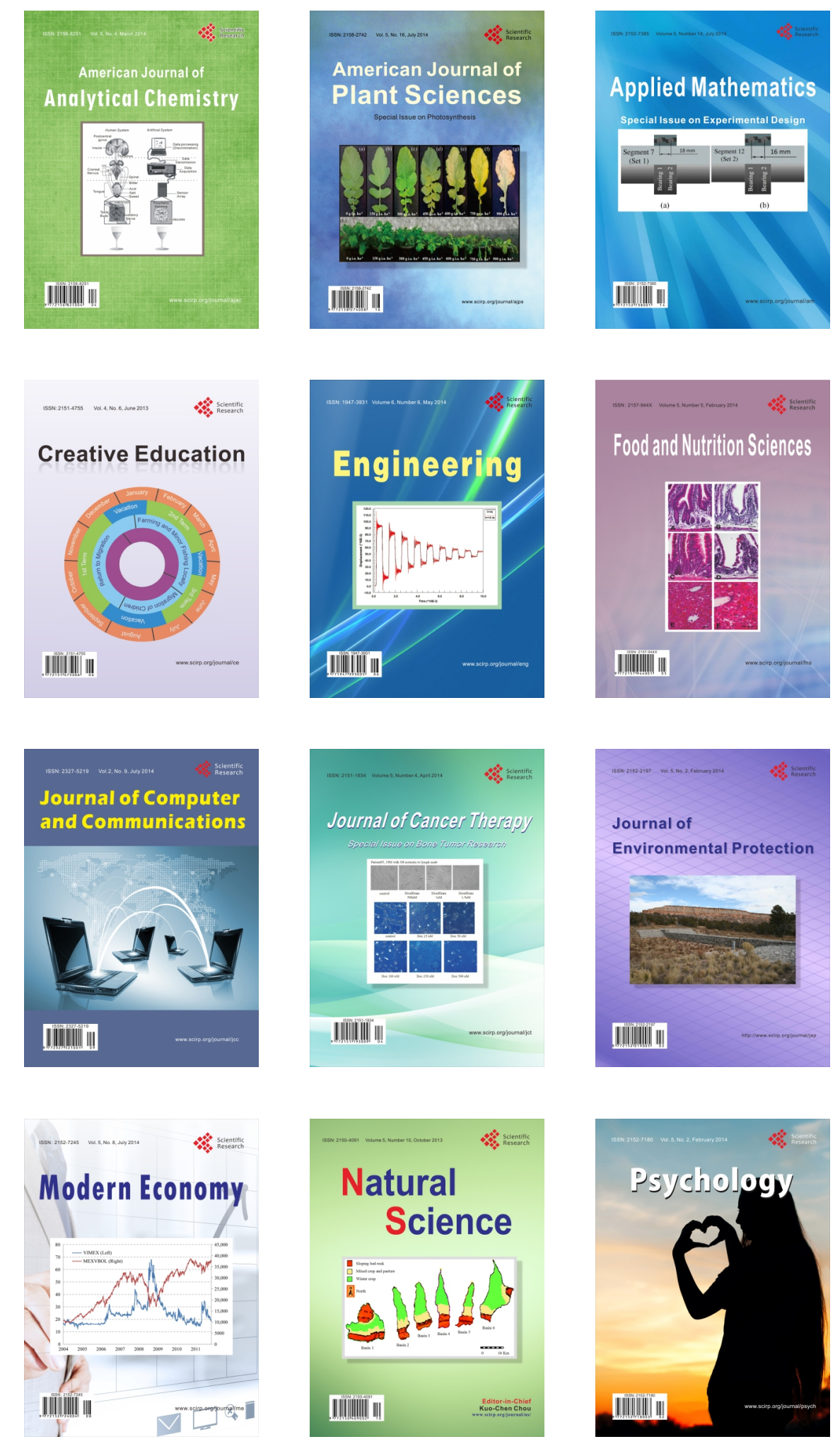